Prophetic: Professional, Empathy and Islamic Counseling Journal

Vol. 2, No. 2, Desember 2019, hlm. 189-202

e-ISSN : 2685-0702, p-ISSN : 2654-3958

Tersedia Online di http://syekhnurjati.ac.id/jurnal/index.php/prophetic

Email: prophetic@syekhnurjati.ac.id

\title{
Bimbingan Kelompok dengan Metode Investigasi Kelompok untuk Mengembangkan Kecerdasan Interpersonal Siswa
}

\author{
Fitri Aprianti \\ Program Studi PGSD, Fakultas Keguruan dan Ilmu Pendidikan, \\ Universitas Muhammadiyah Cirebon \\ aprianti22.fitri@gmail.com
}

\begin{abstract}
Abstrak
Penelitian ini bertujuan menguji efektivitas bimbingan kelompok menggunakan metode investigasi kelompok dalam mengembangkan kecerdasan interpersonal siswa. Dalam penelitian ini digunakan pendekatan kuantitatif, dengan metode penelitian Quasi Experimental. Desain eksperimen yang digunakan adalah desain eksperimen Nonequivalent Pretest-Postest Control Group Design. Penelitian dilakukan di MAN Talaga dengan mengambil subjek penelitian yakni siswa kelas $\mathrm{X}$ yang ditentukan menggunakan teknik purposive sampling (sampel bertujuan). Instrumen penelitian yang digunakan adalah Angket Kecerdasan Interpersonal. Hasil penelitian menunjukkan bahwa intervensi bimbingan kelompok menggunakan metode investigasi kelompok teruji efektif dalam mengembangkan kecerdasan interpersonal siswa.
\end{abstract}

Kata Kunci: Kecerdasan Interpersonal; Metode Investigas Kelompok; Bimbingan Kelompok.

\section{PENDAHULUAN}

Gardner (dalam DePorter et al., 2000) mendefinisikan kecerdasan interpersonal sebagai kecerdasan berpikir lewat berkomunikasi dengan orang lain. Orang yang memiliki kecerdasan interpersonal dengan baik, umumnya pandai dalam memimpin, berorganisasi, berinteraksi, berbagi, menyayangi, berbicara, bersosialisasi, manipulasi, menjadi pendamai, permainan kelompok, berteman, dan bekerjasama dalam kelompok. Kecerdasan interpersonal mempunyai peran penting dalam kehidupan sehari-hari terutama dalam berhubungan dengan orang lain. Dengan kecerdasan interpersonal akan memudahkan seseorang menyesuaikan diri, bersosialisasi dengan orang lain maupun lingkungan, menjadi orang dewasa yang sadar secara sosial, dan akan berhasil dalam pekerjaan (Surya, 2006, hlm. 31).

Kecerdasaan intelektual tak dapat bekerja dengan sebaik-baiknya tanpa kecerdasan interpersonal. Hal ini sesuai dengan pernyataan Goleman (Mansur, 2007, hlm. 56): 
Khusus pada orang-orang yang murni hanya memiliki kecerdasan akademis tinggi, mereka cenderung memiliki rasa gelisah yang tidak beralasan, terlalu kritis, rewel, cenderung menarik diri, terkesan dingin dan cenderung sulit mengekspresikan kekesalan dan kemarahannya secara tepat. Bila didukung dengan rendahnya taraf kecerdasan emosionalnya, maka orang-orang seperti ini sering menjadi sumber masalah. Bila seseorang memiliki IQ tinggi namun taraf kecerdasan interpersonal rendah maka cenderung akan terlihat sebagai orang yang keras kepala, sulit bergaul, mudah frustrasi, tidak mudah percaya kepada orang lain, tidak peka dengan kondisi lingkungan dan cenderung putus asa bila mengalami stress. Kondisi sebaliknya, dialami oleh orang-orang yang memiliki taraf IQ rata-rata namun memiliki kecerdasan interpersonal yang tinggi.

Menurut May Lwin et al. (2008, hlm. 201) kecerdasan interpersonal menjadi penting karena dalam kehidupan manusia tidaklah bisa hidup sendiri, ada ungkapan "No man is an island" (tidak ada orang yang dapat hidup sendiri). Sesungguhnya orang memerlukan orang lain agar mendapatkan kehidupan seimbang secara sosial, emosional dan fisik. Kurangnya kecerdasan interpersonal adalah salah satu akar penyebab tingkah laku yang tidak diterima secara sosial. Individu yang memiliki kecerdasan interpersonal yang rendah nantinya cenderung tidak peka, tidak peduli, egois dan menyinggung perasaan orang lain.

Menurut Goleman (Berlina, 2012, hlm. 53) individu dengan tingkat kecerdasan interpersonal tinggi tidak terlalu mengalami kesulitan dalam membina hubungan dengan orang lain, baik dengan orang yang baru dikenal maupun dengan teman lama. Individu yang memiliki kecerdasan interpersonal tinggi senantiasa berkata dua kali sebelum mengeluarkan kata-kata yang akan diucapkananya, tidak serta merta menanggapi perkataan orang lain secara langsung tanpa dicerna walaupun perkataan itu menurut orang lain cukup meyakinkan. Kebanyakan individu yang memiliki kecerdasan interpersonal yang tinggi pandai mempengaruhi dan tutur kata yang dimiliki lembut baik secara lisan maupun tulisan.

Orang yang memiliki kecerdasan interpersonal yang rendah dapat memunculkan konflik interpersonal. Hal ini ditegaskan oleh Sullivan (Chaplin, 2000, hlm. 257) bahwa penyakit mental dan perkembangan kepribadian terutama sekali lebih banyak ditentukan oleh interaksi interpersonalnya daripada oleh faktor-faktor konstitusionalnya. Siswa yang gagal dalam mengembangkan kecerdasan interpersonal, akan mengalami banyak hambatan dalam dunia sosialnya (Safaria, 2005, hlm. 13). Terlebih lagi, siswa yang masih dalam masa remaja dituntut untuk bisa mengembangkan kehidupan sosialnya. Seperti pendapat Hurlock (1980) bahwa pada masa remaja tugas perkembangan yang tersulit dan terpenting adalah berhubungan dengan penyesuaian sosial. Dalam mencapai tujuan dari pola sosialisasi dewasa, remaja harus membuat banyak penyesuaian yang baru.

Oleh karena itu, perlu adanya pengembangan secara khusus terhadap kecerdasan interpersonal siswa, yakni melalui bimbingan kelompok menggunakan metode investigasi kelompok. Melalui bimbingan kelompok menggunakan metode investigasi kelompok, siswa dilatih untuk dapat berinteraksi dengan siswa lainnya. Investigasi kelompok mengajarkan siswa untuk dapat bekerja sama dengan siswa lain, belajar sebagai unit kelompok, dan hal yang paling penting dalam investigasi kelompok adalah terjadinya proses interaksi antar 
siswa dalam proses pembelajarannya. Seperti yang diungkapkan oleh Armstrong (2004, hlm. 122), kerja kelompok menyediakan kesempatan bagi siswa untuk bekerja sebagai unit sosial.

Metode investigasi kelompok merupakan perpaduan antara bidang sosial dan kemampuan berkomunikasi antar siswa (Slavin, 2008). Dalam investigasi kelompok, kelompok siswa berfungsi sebagai wahana dalam berinteraksi sosial. Dengan demikian penelitian difokuskan pada permasalahan utama yakni bagaimana keefektifan bimbingan kelompok menggunakan metode investigasi kelompok dalam mengembangkan kecerdasan interpersonal siswa.

Permasalahan utama tersebut berimplikasi terhadap permasalahan lainnya yang juga perlu dikaji dalam penelitian ini yakni, (1) perlunya identifikasi terhadap profil kecerdasan interpersonal siswa sebagai acuan bagi perumusan bimbingan kelompok menggunakan metode investigasi kelompok dalam mengembangkan kecerdasan interpersonal siswa, (2) perlunya rancangan bimbingan kelompok menggunakan metode investigasi kelompok yang secara hipotetik efektif dalam mengembangkan kecerdasan interpersonal siswa, dan (3) perlunya pengujian secara empirik terhadap efektivitas bimbingan kelompok menggunakan metode investigasi kelompok dalam mengembangkan kecerdasan interpersonal siswa.

Tujuan dari penelitian ini adalah untuk mengetahui: (1) profil umum kecerdasan interpersonal siswa, (2) rancangan bimbingan kelompok menggunakan metode investigasi kelompok yang diperlukan atau secara hipotetik efektif dalam mengembangkan kecerdasan interpersonal siswa, dan (3) efektivitas bimbingan kelompok menggunakan metode investigasi kelompok dalam mengembangkan kecerdasan interpersonal siswa.

\section{METODE PENELITIAN}

Pendekatan yang digunakan dalam penelitian ini adalah pendekatan kuantitatif, yaitu pendekatan penelitian untuk menjawab pertanyaan penelitian atau hipotesis yang membutuhkan jawaban secara spesifik dengan penggunaan statistik. Dalam penelitian ini, metode yang digunakan adalah eksperimen kuasi dengan desain eksperimen yang digunakan non-equivalent pretest-posttest control group design. Non-equivalent pretest-posttest control group design merupakan desain penelitian yang dilaksanakan terhadap dua kelompok, yakni kelompok eksperimen dan kelompok kontrol. Kelompok eksperimen maupun kelompok kontrol tidak dipilih secara random. Kelompok kontrol merupakan kelompok pembanding. Kedua kelompok dikenakan pengukuran sebanyak dua kali sebelum dan sesudah diberikan perlakuan (Sugiyono, 2012:116).

Penelitian dilakukan di MAN Talaga dengan mengambil subjek penelitian yakni siswa kelas $\mathrm{X}$ yang ditentukan menggunakan teknik purposive sampling (sampel bertujuan). Instrumen penelitian yang digunakan adalah angket/quesioner Kecerdasan Interpersonal. Langkah-langkah penelitian yakni mencakup pre-test (tes awal), pemberian perlakuan (treatment) dan post-test (tes akhir). Teknik analisis data yang digunakan dalam penelitian ini adalah dengan analisis statistik uji $t$ independen (independent sample t-test). Sebelum 
dilakukan uji $t$, langkah pengujian efektivitas bimbingan kelompok menggunakan metode investigasi kelompok terlebih dahulu dilakukan uji normalitas dan uji homogenitas.

\section{HASIL DAN PEMBAHASAN}

Gambaran kecerdasan interpersonal siswa kelas X MAN Talaga diperoleh dari hasil pengumpulan data terhadap 225 orang siswa kelas X MAN Talaga. Data yang diperoleh menunjukan gambaran kecerdasan interpersonal siswa kelas X MAN Talaga memperoleh capaian skor sebesar 73,22\% atau berada pada kategori sedang, dengan skor rata-rata kelas sebesar 287,91. Secara lebih rinci gambaran kecerdasan interpersonal siswa kelas X MAN Talaga disajikan dalam tabel 1 berikut.

\section{Tabel 1}

Profil Kecerdasan Interpersonal Siswa

\begin{tabular}{|l|l|l|l|l|l|}
\hline Subjek & $\begin{array}{l}\text { Capaian } \\
\text { Skor }\end{array}$ & $\begin{array}{l}\text { Rata-Rata } \\
\text { Kelas }\end{array}$ & Frekuensi & $\begin{array}{l}\text { Persentse } \\
(\boldsymbol{\%})\end{array}$ & Kategori \\
\hline \multirow{3}{*}{ Kelas X } & \multirow{2}{*}{$73,22 \%$} & 287,91 & 124 & 55,11 & Tinggi \\
\cline { 4 - 6 } & & 101 & 44,89 & Sedang \\
\cline { 3 - 6 } & & 0 & 0 & Rendah \\
\hline
\end{tabular}

Profil kecerdasan interpersonal siswa kelas X MAN Talaga dilihat berdasarkan setiap aspek kecerdasan interpersonal. Secara lebih rinci capaian skor tingkat kecerdasan interpersonal berdasarkan setiap aspek disajikan dalam grafik 1 berikut.

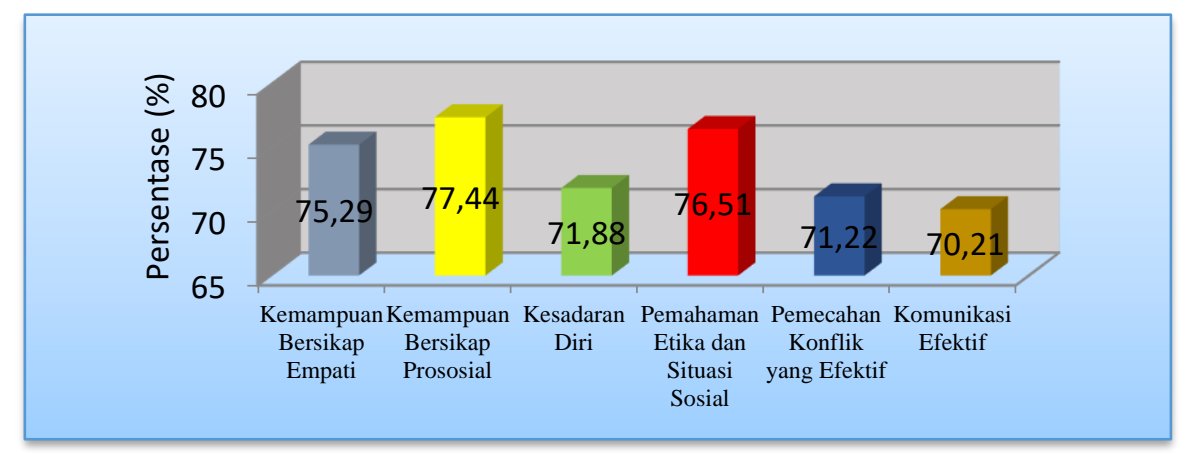

\section{Grafik 1}

\section{Tingkat Kecerdasan Interpersonal Setiap Aspek}

Untuk lebih rinci mengenai keefektifan bimbingan kelompok menggunakan metode investigasi kelompok dibawah ini akan dijelaskan mengenai perbandingan pencapaian skor kecerdasan interpersonal kelas eksperimen dan kelas kontrol pada tes awal (pre-test) dan tes akhir (post-test). 


\section{Kelas Eksperiman (Kelas X-3)}

Berdasarkan pada hasil perhitungan pencapaian skor kecerdasan interpersonal yang diperoleh kelas eksperimen pada tes awal (pre-test) dan tes akhir (post-test) disajikan dalam grafik 2 berikut.

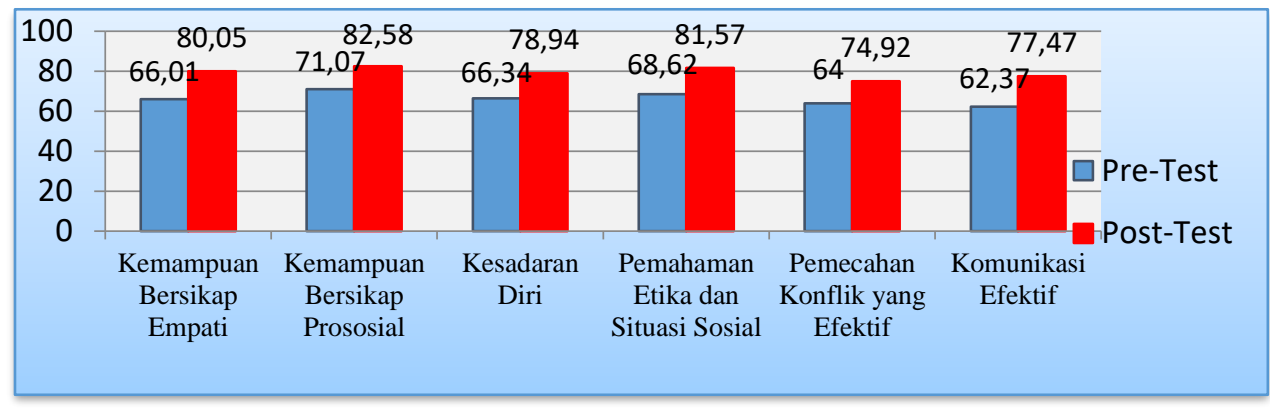

\section{Grafik 2}

\section{Capaian Skor Kecerdasan Interpersonal Kelas Eksperimen (Kelas X-3)}

\section{pada Tes Awal (Pre-test) dan Tes Akhir (Post-Test)}

Berdasarkan grafik 2 diatas terlihat perbandingan capaian skor kecerdasan interpersonal kelas eksperimen pada tes awal (pre-test) dan tes akhir (post-test), dan terjadi peningkatan yang signifikan capaian skor kecerdasan interpersonal kelas eksperimen.

\section{Kelas Kontrol (Kelas X-4)}

Berdasarkan pada hasil perhitungan pencapaian skor kecerdasan interpersonal yang diperoleh kelas kontrol pada tes awal (pre-test) dan tes akhir (post-test) disajikan dalam grafik 3 berikut.

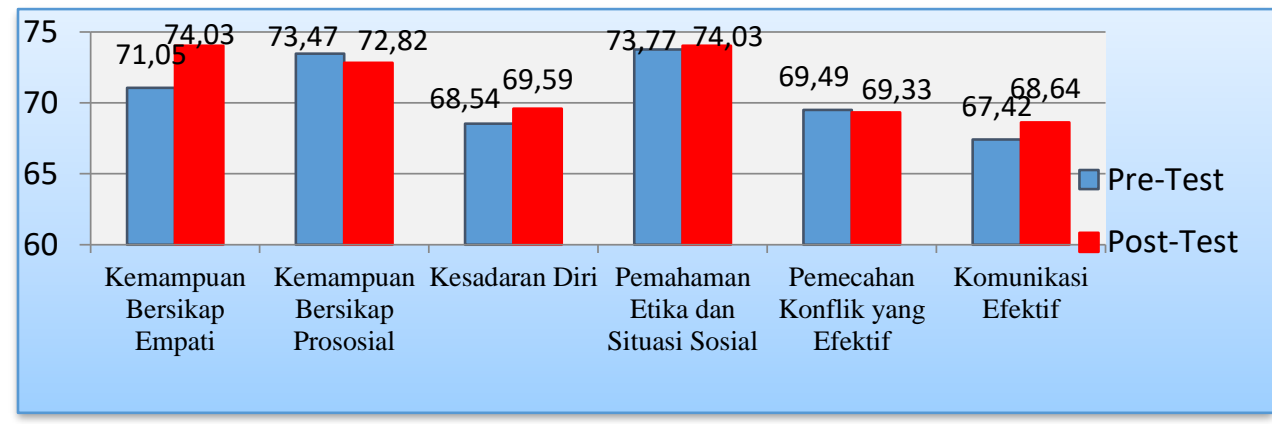

\section{Grafik 3}

\section{Capaian Skor Kecerdasan Interpersonal Kelas Kontrol (Kelas X-4) pada}

Tes Awal (Pre-test) dan Tes Akhir (Post-Test)

\section{Perbandingan Kelas Eksperimen dan Kelas Kontrol}

Untuk melihat keefektifan bimbingan kelompok menggunakan metode investigasi kelompok dalam mengembangkan kecerdasan interpersonal siswa dapat dilihat dari perbandingan capaian skor kecerdasan interpersonal kelas eksperimen dan kelas kontrol pada tes awal atau sebelum diberikannya perlakuan terhadap kelas eksperimen, dan pada tes akhir atau setelah diberikannya perlakuan terhadap kelas eksperimen. Kelas kontrol 
yang merupakan kelas pembanding tidak mendapatkan perlakuan seperti halnya kelas eksperimen. Sehingga capaian skor kecerdasan interpersonal yang diperoleh oleh kelas eksperimen dan kelas kontrol akan diketahui bagaimana keefektifan bimbingan kelompok menggunakan metode investigasi kelompok.

Perbandingan capaian skor kecerdasan interpersonal kelas eksperimen dan kelas kontrol pada tes awal atau sebelum diberikannya perlakuan terhadap kelas eksperimen, disajikan dalam grafik 4 berikut.

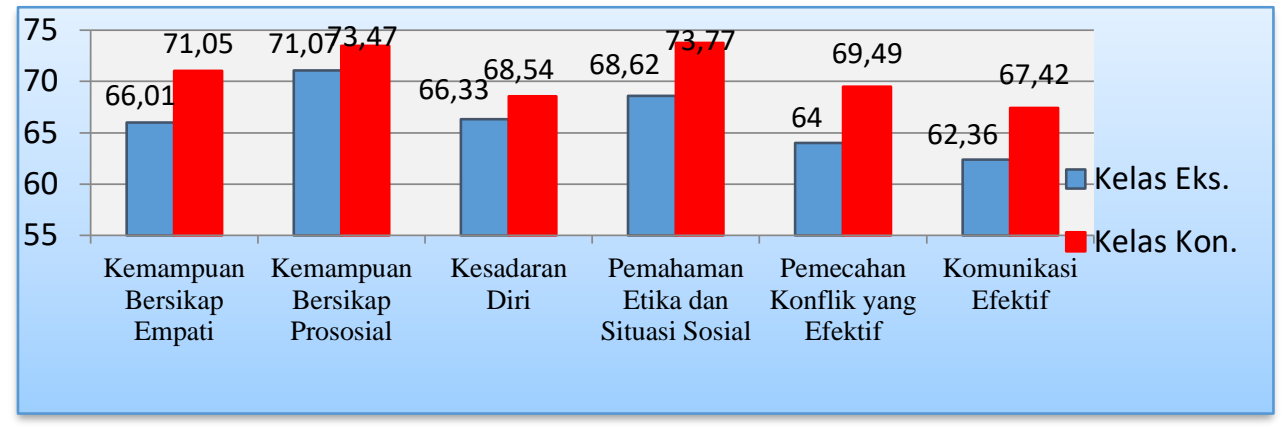

Grafik 4

\section{Perbandingan Capaian Skor Kecerdasan Interpersonal Kelas Eksperimen dan}

Kelas Kontrol pada Tes Awal (Pre-Test)

Berdasarkan pada grafik diatas, capaian skor kecerdasan interpersonal yang diperoleh oleh kelas eksperimen lebih rendah daripada capaian skor kecerdasan interpersonal kelas kontrol. Hasil ini lah yang dijadikan acuan dalam memberikan bimbingan kelompok menggunakan metode investigasi kelompok kepada kelas eksperimen, sehingga diharapkan setelah diberikannya perlakuan terhadap kelas eksperimen, capaian skor kecerdasan interpersonal kelas eksperimen menjadi lebih tinggi daripada capaian skor kecerdasan interpersonal kelas kontrol.

Untuk melihat bagaimana perubahan capaian skor kecerdasan interpersonal kelas eksperimen setelah diberikannya perlakuan berupa bimbingan kelompok menggunakan metode investigasi kelompok, disajikan dalam grafik 5 berikut.

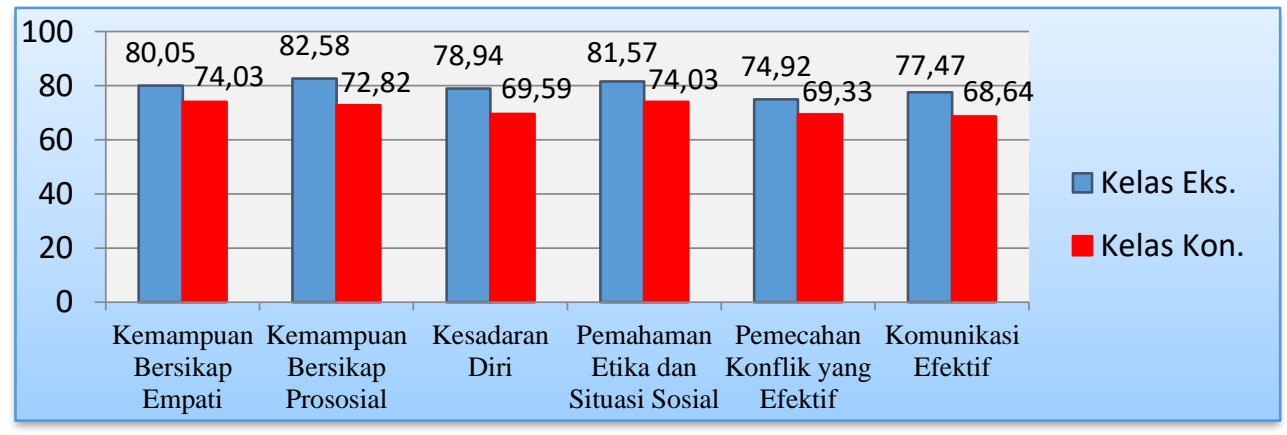

\section{Grafik 5}

Perbandingan Capaian Skor Kecerdasan Interpersonal Kelas Eksperimen dan Kelas Kontrol pada Tes Akhir (Post-Test) 
Berdasarkan hasil yang tertera dalam grafik 5 diatas, terlihat bahwa semua aspek dalam kecerdasan interpersonal mengalami peningkatan yang signifikan. Hal ini menunjukkan bahwa capaian skor setiap aspek kecerdasan interpersonal kelas eksperimen lebih tinggi dibandingkan dengan capaian skor setiap aspek kecerdasan interpersonal kelas kontrol. Dari hasil yang diperoleh kelas eksperimen, mengindikasikan bahwa bimbingan kelompok menggunakan metode investigasi kelompok terbukti efektif dalam mengembangkan kecerdasan interpersonal siswa

\section{Pembahasan}

Berdasarkan hasil penelitian menunjukkan bahwa secara umum profil kecerdasan interpersonal siswa kelas X MAN Talaga berada pada tingkat sedang. Hal ini terlihat dari pencapaian skor aspek kecerdasan interpersonal yang mayoritas berada pada tingkatan sedang, terdapat lima aspek kecerdasan interpersonal yang berada pada tingkatan sedang, yaitu aspek kemampuan bersikap empati, aspek kesadaran diri, aspek pemahaman etika dan situasi sosial, aspek pemecahan masalah (konflik) secara efektif, dan aspek kemampuan komunikasi efektif. Sedangkan satu aspek yang berada pada tingkatan tinggi yaitu aspek kemampuan bersikap prososial.

Hal ini menunjukkan bahwa siswa kelas X MAN Talaga memiliki kecerdasan interpersonal yang cukup optimal pada setiap dimensi kecerdasan interpersonal, yaitu dimensi kepekaan sosial (social sensitivity), dimensi wawasan sosial (social insight), dan dimensi komunikasi sosial (social communication). Artinya siswa cukup mampu bersikap empati terhadap orang lain, cukup mampu untuk bersikap prososial, cukup memiliki kesadaran diri, cukup memahami etika sosial dan situasi sosial, cukup mampu memecahkan masalah (konflik) dengan efektif, dan cukup memiliki keterampilan untuk menampilkan komunikasi secara efektif.

Apabila tingkat kecerdasan interpersonal siswa yang masih berada pada kategori sedang dibiarkan begitu saja, maka dikhawatirkan kecerdasan interpersonal siswa akan menurun menjadi rendah. Sebagaimana yang diungkapkan oleh Safaria (2005:13) bahwa kecerdasan interpersonal sangat penting dimiliki semua siswa karena pada dasarnya manusia tidak bisa menyendiri. Siswa yang gagal dalam mengembangkan kecerdasan interpersonal, akan mengalami banyak hambatan dalam dunia sosialnya (Safaria, 2005:13).

Beberapa penelitian sebelumnya mengenai kecerdasan interpersonal, menunjukkan beberapa hasil yang sejalan dengan hasil penelitian ini. Penelitian yang dilakukan oleh Center for Creative Leadership di Greensboro, North Carolina, membandingkan 21 eksekutif yang gagal dengan 20 eksekutif yang berhasil menduduki puncak organisasi, hasil penelitian menemukan bahwa, eksekutif yang gagal bukan karena tidak ahli di bidangnya, tetapi karena tidak memiliki kecerdasan interpersonal khususnya dalam membina hubungan dengan orang lain (McCall \& Lombardo, 1983). 
Berdasarkan hasil penelitian yang dilakukan oleh Hartati (2009) terhadap siswa kelas XI SMAN 8 Bandung tahun ajaran 2008/2009 diperoleh hasil yang menunjukkan bahwa siswanya sebagian besar memiliki tingkat kecerdasan interpersonal pada kategori sedang. Hal ini berarti bahwa secara umum siswa telah memiliki kecerdasan interpersonal tetapi belum mampu mengaplikasikannya secara optimal, dan masih memerlukan pengembangan kecerdasan interpersonal.

Penelitian yang dilakukan oleh Berlina (2012) diperoleh hasil kecerdasan interpersonal siswa kelas VIII SMP Negeri 5 Bandung Tahun Pelajaran 2011/2012 umumnya berada pada kategori sedang, yang berarti bahwa siswa memiliki kecerdasan interpersonal yang cukup memadai, ditandai dengan kemampuan siswa dalam wawasan sosial, kepekaan sosial, dan keterampilan menjalin komunikasi sosial, akan tetapi kecerdasan interpersonal yang ada belum maksimal dan masih harus dikembangkan guna mempertahankan suatu hubungan antar pribadi (sosial) yang sehat dan saling menguntungkan.

Penelitian lainnya yang dilakukan oleh Mirna (2009) terhadap siswa akselerasi SMAN 5 Bandung diperoleh hasil bahwa secara umum siswanya memiliki tingkat kecerdasan interpersonal dalam kategori sedang, yang tersebar pada setiap kategori pencapaian yaitu tinggi 47,62\%, sedang 52,38\%, dan rendah 0\%. Berdasarkan hasil penelitian ini menunjukkan siswa akselerasi masih membutuhkan pengembangan dan pengoptimalan kecerdasan interpersonal.

Berdasarkan grafik 1 diatas, aspek kemampuan bersikap prososial merupakan aspek yang memperoleh capaian skor kecerdasan interpersonal tertinggi dengan skor $77,44 \%$ atau berada pada kategori tinggi. Hal ini menunjukkan bahwa siswa mampu bertindak tanpa menuntut keuntungan ketika memberikan bantuan, mampu bertindak secara sukarela, dan mampu bertindak untuk menghasilkan kebaikan.

Aspek berikutnya yang memperoleh capaian skor kecerdasan interpersonal yang tinggi yaitu aspek pemahaman etika dan situasi sosial dengan skor 76,51\% atau berada pada kategori sedang, hal ini menunjukkan bahwa siswa cukup memahami perilaku yang harus dilakukan, cukup memahami perilaku yang dilarang untuk dilakukan, dan cukup memahami norma moral dan sosial yang berlaku di masyarakat. Diikuti oleh aspek kemampuan bersikap empati yang memperoleh capaian skor kecerdasan interpersonal sebesar 75,29\% atau berada pada kategori sedang, hal ini menunjukkan bahwa siswa cukup mampu menerima sudut pandang orang lain, cukup memiliki kepekaan terhadap perasaan orang lain, dan cukup mampu mendengarkan orang lain.

Sementara itu, aspek yang memperoleh capaian skor kecerdasan interpersonal lebih rendah yaitu aspek kesadaran diri yang memperoleh capaian skor kecerdasan interpersonal sebesar 71,88\% atau berada pada kategori sedang, hal ini menunjukkan bahwa siswa cukup menyadari kekhasan fisik, kepribadian, watak, dan tempramennya, cukup mengenal bakatbakat alamiah yang dimilikinya, dan cukup menyadari gambaran diri sendiri dengan segala kekuatan dan kelemahannya. 
Aspek berikutnya yaitu aspek pemecahan masalah (konflik) yang efektif yang memperoleh capaian skor kecerdasan interpersonal sebesar 71,22\% atau berada pada kategori sedang, hal ini menunjukkan bahwa siswa cukup mampu menentukan strategi pemecahan konflik yang efektif yakni kolaborasi, mengalah, mendominasi, menghindar, dan kompromi.

Aspek yang memperoleh capaian skor kecerdasan interpersonal terendah yaitu aspek komunikasi efektif dengan skor 70,21\% atau berada pada kategori sedang, hal ini menunjukkan bahwa siswa cukup memiliki keterampilan berbicara dengan orang lain, dan cukup memiliki keterampilan mendengarkan efektif.

Secara umum profil kecerdasan interpersonal siswa kelas X MAN Talaga tahun ajaran 2012/2013 berada pada tingkat sedang. Hal ini terlihat dari pencapaian skor aspek kecerdasan interpersonal yang mayoritas berada pada tingkatan sedang, terdapat lima aspek kecerdasan interpersonal yang berada pada tingkatan sedang, yaitu aspek kemampuan bersikap empati, aspek kesadaran diri, aspek pemahaman etika dan situasi sosial, aspek pemecahan masalah (konflik) secara efektif, dan aspek kemampuan komunikasi efektif. Sedangkan satu aspek yang berada pada tingkatan tinggi yaitu aspek kemampuan bersikap prososial.

Efektivitas bimbingan kelompok menggunakan metode investigasi kelompok dalam mengembangkan kecerdasan interpersonal siswa kelas X MAN Talaga di uji menggunakan analisis statistik, yakni dengan menggunakan uji t yaitu Independent Sample T-Test. Dari pengujian ini akan diperoleh gambaran mengenai perbedaan rata-rata tes awal (pre-test) dengan rata-rata tes akhir (post-test). Berdasarkan hasil analisis data, diketahui bahwa bimbingan kelompok menggunakan metode investigasi kelompok terbukti efektif dalam mengembangkan kecerdasan interpersonal siswa. Capaian skor tingkat kecerdasan interpersonal kelas eksperimen mengalami peningkatan yang signifikan, tersaji dalam grafik 6 berikut.

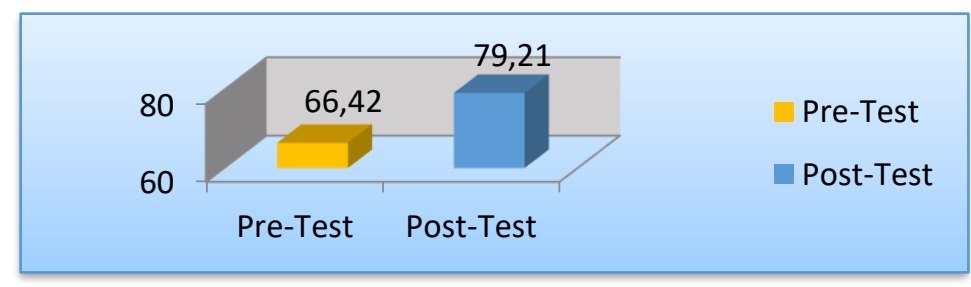

\section{Grafik 6}

\section{Capaian Skor Tingkat Kecerdasan Interpersonal Kelas Eksperimen}

Berdasarkan grafik 6 terlihat tingkat kecerdasan interpersonal kelas eksperimen meningkat secara signifikan, tingkat kecerdasan interpersonal kelas eksperimen pada tes awal (pre-test) sebesar 66,42\% atau berada pada kategori sedang. Setelah diberikan perlakuan, tingkat kecerdasan interpersonal kelas eksperimen pada tes akhir (post-test) mengalami peningkatan sebesar $12,79 \%$ menjadi 79,21\% atau meningkat menjadi kategori tinggi. Sementara itu, pada kelas kontrol yang tidak diberikan perlakuan tingkat kecerdasan 
interpersonalnya tetap meningkat tetapi peningkatannya hanya sedikit. Pada tes awal (pretest) tingkat kecerdasan interpersonalnya sebesar 70,73\% atau berada pada kategori sedang, dan pada tes akhir (post-test) tingkat kecerdasan interpersonalnya menjadi sebesar 71,47\% atau tetap pada kategori sedang.

Terjadinya peningkatan hasil kecerdasan interpersonal dari kelas eksperimen bisa disebabkan oleh beberapa alasan. Alasan pertama karena adanya pengaruh pemberian program intervensi terhadap kelas eksperimen berupa layanan bimbingan kelompok menggunakan metode investigasi kelompok. Seperti yang diungkapkan oleh Safaria (2005:42) bahwa kecerdasan interpersonal tidak dibawa sejak lahir, namun diperoleh melalui proses belajar yang berkesinambungan.

Alasan berikutnya adalah karena kecerdasan interpersonal seseorang bisa dikembangkan sampai pada tingkat tertinggi, karena kecerdasan interpersonal pada dasarnya dapat dikembangkan dengan bantuan pengajaran atau pendekatan yang tepat. Seperti yang dikemukakan oleh Gardner (2003:79) bahwa pengembangan kecerdasan bisa dicapai untuk setiap jenis kecerdasan termasuk kecerdasan interpersonal, dan tergantung dari proses pendidikan atau pembelajaran yang spesifik terhadap kecerdasan tersebut. Hal senada juga dikemukakan oleh Armstrong (2004:17), setiap orang mampu mengembangkan kecerdasan majemuknya (didalamnya termasuk kecerdasan interpersonal) sampai pada kinerja tingkat tinggi yang memadai apabila memperoleh cukup dukungan, pengayaan, dan pengajaran.

Dalam investigasi kelompok, siswa diberikan kesempatan untuk mengungkapkan gagasan dan pengalamannya kepada orang lain agar dapat belajar secara optimal. Selain itu, siswa yang merupakan makhluk sosial akan dapat merasakan manfaat dari belajar kelompok. Armstrong (2004:119) mengungkapkan bahwa semua siswa memiliki derajat kecerdasan interpersonal yang berbeda-beda, konselor (pendidik) perlu mengetahui pendekatan yang melibatkan interaksi antar siswa.

Dalam bimbingan kelompok menggunakan metode investigasi kelompok, siswa dilatih untuk dapat berinteraksi dengan siswa lainnya. Investigasi kelompok mengajarkan siswa untuk dapat bekerja sama dengan siswa lain, belajar sebagai unit kelompok, dan hal yang paling penting dalam investigasi kelompok adalah terjadinya proses interaksi antar siswa dalam proses pembelajarannya. Seperti yang diungkapkan oleh Armstrong (2004:122), kerja kelompok menyediakan kesempatan bagi siswa untuk bekerja sebagai unit sosial. Sebuah syarat penting apabila ingin berhasil mengembangkan kecerdasan interpersonal di lingkungan sekolah.

Metode investigasi kelompok merupakan perpaduan antara bidang sosial dan kemampuan berkomunikasi antar siswa. Slavin (2008:215) mengungkapkan bahwa metode investigasi kelompok tidak dapat diimplementasikan dalam kelas yang tidak mendukung dialog interpersonal atau yang tidak memperhatikan dimensi sosial dalam pembelajarannya. Dalam investigasi kelompok, kelompok siswa berfungsi sebagai wahana dalam berinteraksi sosial.

Dalam penelitiannya, Zingaro (2008) mengungkapkan bahwa faktanya investigasi kelompok telah menunjukkan keuntungan dan kelebihan untuk tipe pembelejaran kooperatif 
dengan sangat baik, dan ditemukan hasil bahwa investigasi kelompok meningkatkan hubungan interpersonal yang positif dan meningkatkan motivasi intrinsik.

Siswa dalam investigasi kelompok akan menunjukkan sikap kooperatif dan prososial, bahkan ketika berinteraksi dengan siswa lain diluar kelompoknya atau dalam situasi sosial diluar kelasnya. Investigasi kelompok juga membangkitkan kemampuan siswa untuk dapat mengekspresikan dirinya, memiliki kesadaran diri dan bertanggung jawab, serta mengembangkan rasa untuk bisa diterima oleh orang lain. Investigasi kelompok telah terbukti meningkatkan hubungan interpersonal siswa, kepercayaan, dan lebih banyak lagi sikap positif yang mendukung siswa baik disekolah maupun dalam belajar. Selain itu, investigasi kelompok mampu mengurangi hubungan yang kurang baik antar etnik, hubungan interpersonal yang tidak baik dapat dikurangi dengan investigasi kelompok.

Berdasarkan hasil penelitian yang dilakukan oleh Setyarini (2009) menunjukkan hasil bahwa kecerdasan interpersonal siswa meningkat setelah pemberian investigasi kelompok. Siswa memperoleh pengalaman belajar yang baru yaitu adanya hubungan interpersonal antar siswa yang dapat menjalin interaksi positif antar siswa dalam satu kelompok maupun dalam kelas.

\section{SIMPULAN}

Berdasarkan hasil penelitian menunjukkan bahwa secara umum profil kecerdasan interpersonal siswa kelas X MAN Talaga tahun ajaran 2012/2013 berada pada tingkat sedang. Hal ini terlihat dari pencapaian skor aspek kecerdasan interpersonal yang mayoritas berada pada tingkatan sedang, terdapat lima aspek kecerdasan interpersonal yang berada pada tingkatan sedang, yaitu aspek kemampuan bersikap empati, aspek kesadaran diri, aspek pemahaman etika dan situasi sosial, aspek pemecahan masalah (konflik) secara efektif, dan aspek kemampuan komunikasi efektif. Sedangkan satu aspek yang berada pada tingkatan tinggi yaitu aspek kemampuan bersikap prososial. Berdasarkan hasil uji efektivitas, intervensi metode investigasi kelompok terbukti efektif dalam mengembangkan kecerdasan interpersonal siswa kelas X MAN Talaga.

\section{DAFTAR PUSTAKA}

Armstrong, T. (2004). Sekolah Para Juara: Menerapkan Multiple Intelligences di Dunia Pendidikan. Bandung: Kaifa.

Berlina, B. (2012). Profil Kecerdasan Interpersonal Siswa dan Implikasinya Bagi Bimbingan dan Konseling. Skripsi. PPB FIP UPI Bandung. Tidak Diterbitkan.

Chaplin, J. P. (2000). Kamus Lengkap Psikologi (Terjemahan Kartono, K). Jakarta: PT Raja Grafindo Persada.

Feningstein, A. (1979). Self-Consciousness, Self-Attention, and Social Interaction. Journal of Personality and Social Psychology. 37, 75-86. 
Franzoi, S. L. (1983). Self-Concept Differences as a Function of Private Self Consciousness and a Social Anxiety. Journal of Research in Personality. 17, 275-287.

Gardner, H. (2003). Multiple intelligences (Kecerdasan Majemuk). Batam: Interaksara.

Greenberger, E., Josselson, R., Knerr, C., and Knerr, B. (1975). "The Measurement and Structure of Psychosocial Maturity". Journal of Youth and Adolescence. 4, 127-143.

Hartati, A. (2009). Program Bimbingan dan Konseling Pribadi-Sosial untuk Mengembangkan Kecerdasan Interpersonal Siswa. Skripsi. PPB FIP UPI Bandung. Tidak Diterbitkan.

Indiyani, N. E., Widodo, P. B., Listiara, A. (2006). Efektivitas Metode Pembelajaran Gotong Royong (Cooperative Learning) untuk Menurunkan Kecemasan Siswa dalam Menghadapi Pelajaran Matematika. Jurnal Psikologi. 3, (1), 10-28.

McCall, M. \& Lombardo, M. (1983). Off the Track: Why and You Successful Executives Get Gerailed. Technical Report No.21, Center for Creative Leadership. Greensboroo, NC.

Mirna, R. (2009). Program Bimbingan dan Konseling untuk Mengembangkan Kecerdasan Intrapersonal dan Kecerdasan Interpersonal Anak Berbakat Akademik. Skripsi. PPB FIP UPI Bandung. Tidak Diterbitkan.

Perkins, H. W., Craig, D. W., and Perkins J. M. (2011). Using Social Norms to Reduce Bullying: A Research Intervention Among Adolescents in Five Middle Schools. Journal of Group Processes \& Intergroup Relation. 14, (5), 703-722.

Purwati, S. dkk. (2012). Model Bimbingan Kelompok dengan Teknik Fun Game untuk Mengurangi Kecemasan Berbicara Didepan Kelas. Jurnal Bimbingan Konseling. 1, (2), 81-87.

Ramdhani, N. dkk. (2003). Empati dan Perilaku Merokok di Tempat Umum, Jurnal Psikologi. 30, (2), 81-90.

Safaria, T. (2005). Interpersonal Intelligence: Metode Pengembangan Kecerdasan Interpersonal Anak. Yogyakarta: Amara Books.

Schultz, P. W., Khazian, A. M., \& Zaleski, A. C. (2008). Using Normative Social Influence To Promote Conservation Among Hotel Guests. Social Influence. 3, (1), 4-23.

Setyarini, T. (2009). Peningkatan Partisipasi Siswa dalam Pembelajaran Biologi melalui Perangsangan Kecerdasan Interpersonal Siswa dengan Penerapan Metode Group Investigation (GI) Di Kelas Vii C SMP Negeri 5 Surakarta. Skripsi. Fakultas Keguruan dan Ilmu Pendidikan Universitas Sebelas Maret Surakarta. Tidak Diterbitkan. 
Slavin, R. (2008). Cooperative Learning: Teori Riset Dan Praktik. Bandung: Nusamedia.

Sugiyono. (2012). Metode Penelitian Pendidikan (Cet.Ke-15). Bandung: Alfabeta.

Susanto, H. (2005). Penerapan Multiplle Intelligence dalam Sistem Pembelajaran. Jurnal Pendidikan Penabur - No.04/ Th.IV/ Juli 2005. 3-4.

Zingaro, D. (2008). Group Investigation: Theory and Practice. Journal International of Group Investigation. [Online] Tersedia: http://www.danielzingaro.com/gi.pdf (Diunduh 2 Agustus 2012). 
202 | Aprianti - Bimbingan Kelompok dengan ... 